\title{
Comparison of neuropsychological factors in pregnant women who continue and quit smoking
}

\author{
Sigara içmeye devam eden ve sigara içmeyi kesen gebelerde nöropsikolo- \\ jik faktörlerin karşılaştırılması
}

Buket Belkız Güngör1', Ersin Budak2 ${ }^{2}$, Mahmut Güngör3 ${ }^{3}$ ỉbrahim Taymur ${ }^{4}$

${ }^{1}$ M.D., Prof. Dr. Mazhar Osman Bakırköy Psychiatry and Neurological Disease Training and Research Hospital, Psychiatry Clinic, Istanbul, Turkey https://orcid.org/0000-0001-7227-5167

${ }^{2}$ Clin. Psch, Bursa Yüksek İhtisas Training and Research Hospital, Psychology, Bursa, Turkey https://orcid.org/0000-0002-6507-505X

3 M.D., İstanbul Bagcılar Training and Research Hospital, Gynecology and Obstetrics, Perinatology Clinic, Istanbul, Turkey

https://orcid.org/0000-0002-6468-5702

${ }^{4}$ Assoc. Prof., Bursa Yüksek İhtisas Training and Research Hospital, Psychiatry Clinic, Bursa, Turkey https://orcid.org/0000-0003-3928-3194https://orcid.org/0000-0002-7017-4730

\section{SUMMARY}

Objective: Little is known about the neuropsychological factors on quitting smoking. The pregnancy period is a natural process in which women are encouraged to quit smoking. This study aimed to compare trait and behavioural impulsivity and planning ability among pregnant women who continue smoking, quit smoking and never smoke. Method: Twenty-seven pregnant women who continue smoking, 15 pregnant women who quit smoking and 28 pregnant women who never smoke and 18 non-pregnant women completed psychometric cognitive tests and psychiatric rating scales. Decision making, planning, response inhibition and trait impulsivity were evaluated with lowa Gambling Task, Tower of London Task, Stroop Task and Barratt Impulsivity Scale, respectively. The severity of physical addiction to nicotine was assessed with Fagerstrom Scale. Results: The non-planning impulsivity was higher in pregnant women who quit smoking rather than smoker, never smoke pregnant control and non-pregnant group $(p=0.010)$. The logistic regression results revealed that non-planning impulsivity was a significant independent contributor to quitting smoking. The percentage of the variance explained by non-planning impulsivity in quitting smoking was $10 \%$. Pregnant women who never smoke showed better performance on TOL rather than smoker group $(p=0.021)$. Although statistically non-significant, motor and attentional impulsivity in never smoke group was lower than that in the ever been smoker group. Discussion: This study revealed that the nonplanning impulsivity was statistically higher in pregnant women who quit smoking rather than smoker group. Increased non-planning impulsivity was found to be a significant factor that contributes to quit smoking.

Key Words: Quit smoking, impulsivity, non-planning impulsivity, planning, decision making, pregnancy

\section{ÖZET}

Amaç: Sigarayı bırakma üzerine etkisi olan nöropsikolojik faktörlerle ilgili bilinenler azdır. Gebelik sigara bırakmak için kadınların teşvik edildiği doğal bir süreçtir. Bu çalışmada sigara içmeye devam eden, sigarayı bırakan ve hiç sigara içmemiş gebe kadınlarda trait ve davranışsal dürtüsellik ve planlama becerisinin karşılaştırılması amaçlandı. Yöntem: Sigara içmeye devam eden 27, sigara içmeyi kesen 15, hiç sigara içmemiş 28 gebe ve gebe olmayan 18 kadın psikometrik kognitif testleri ve ölçekleri tamamladı. Karar verme, planlama, yanıt inhibisyonu ve trait dürtüsellik sırasıyla lowa Kumar Testi, Londra Kulesi Testi, Stroop Testi ve Barratt Impulsivite Ölçeği ile değerlendirildi. Nikotine fiziksel bağımlıı̆̆ın şiddeti Fagerstrom ölçeği ile değerlendirildi. Bulgular: Sigarayı bırakan gebelerde plan yapmama dürtüselliği sigara içmeye devam eden gebeler, hiç sigara içmemiş gebeler ve gebe olmayan kadınlara göre daha fazlaydı $(p=0.010)$. Lojistik regresyon analizi plan yapmama dürtüselliğin sigarayı bırakmaya katkıda bulunan bağımsız bir faktör olduğunu ortaya koydu. Sigarayı bırakmada plan yapmama dürtüselliğin varyansın \%10'unu açıkladığı saptandı. Hiç sigara içmemiş gebeler, sigara içen gebelere gore TOL'da daha iyi performans gösterdiler $(p=0.021)$. İstatiksel olarak anlamlı olmasa da hiç sigara içmemiş grupta motor ve dikkat dürtüsellik sigara kullanımına başlamış gruba gore daha düşüktü. Sonuç: Bu çalışma sigarayı bırakan grupta plan yapmama dürtüselliğinin sigara kullanımına devam eden gruba göre istatiksel olarak anlamlı olacak şekilde yüksek olduğunu ortaya koydu. Plan yapmama dürtüselliğinin sigarayı bırakmaya katkıda bulunan anlamlı bir faktör olduğu bulundu.

Anahtar Sözcükler: Sigarayı bırakma, dürtüsellik, plan yapmama dürtüselliği, planlama, karar verme, gebelik 


\section{INTRODUCTION}

Pregnancy is a dilemma and a burden with regard to nicotine addiction among pregnant women who must decide whether to continue or stop smoking. A plan for quittting smoking is an important priority for pregnant women. At present, public information and education elaborates the harmful effects of smoking on the health of growing foetus. Whether to continue or quit smoking is an important issue when a pregnancy is discovered or planned. Some pregnant women who smoke prior to pregnancy tend to quit smoking upon learning of a pregnancy, but some of them continue. A study that was conducted in our country determined that nearly half of pregnant women who smoke continued to do so at a rate of $\% 42.5$ (1). High prenatal smoking rates are associated with symptoms of depression, being single, low education levels, lifetime smoking and smoking during a previous pregnancy $(1,2)$. Neuropsychological differences could be the underlying mechanism for the continuation or quitting of addicted substances. In the present study, we aim to investigate the neuropsychological differences between pregnant women who can discontinue smoking and those who choose to continue.

Several studies have assessed the environmental, physical and medical factors that affect the rate of quitting smoking (1-4). Studies that investigated factors associated with quitting smoking focus especially on socio-demographic features, the severity of nicotine dependence and the clinical properties of tobacco usage (1-4). A number of researchers have evaluated the executive functions related to the effects of addictive substances and previous neuropsychological risk factors that predispose one to addiction $(5,6)$. However, few studies perform a neuropsychological assessment of former and current smokers in terms of addicts who are capable of quitting and those who are not. (7-9) Moreover few studies assess particular neuropsychological features in smokers who encounter an important reason to stop smoking $(9,10)$. Research on the characteristic features of current and former smokers found that former smokers had higher scores of harm avoidance, along with lower scores of self-directedness and persistence (11). Increased novelty seeking has been associated with failure to quit smoking (12). White reports that increased delay discounting was negatively correlated with quitting smoking during pregnancy (10). These studies suggest that neuropsychological functions and personality traits could be mediating factors that affect quitting smoking.

Impulsivity has different dimensions. Trait impulsivity includes attention impulsivity, motor impulsivity and non-planning impulsivity (13). Response inhibition and decision making are cognitive processes that regulate impulsive behaviour (14). Acting without forethought, i.e. impulsive action, prevents initial quitting. Preferring small early rewards, compared with large postponed rewards, i.e. impulsive choice, negatively affects maintaining abstinence (7). Quitting smoking has been related to successfully maintaining abstinence. Successfully maintaining abstinence, or a low relapse rate of smoking, has been associated with low levels of impulsivity (4).

There are different circumstances that require quitting smoking or the use of other addictive substances, such as an important health problem or problems related with relationships and work. Pregnancy is a natural process in which women are encouraged to quit smoking, and is one of the wellknown, common and main reasons for female smokers to discontinue smoking. This study was conducted with a group of pregnant women group who have at the same important reason to stop smoking. Women are faced with the decision to attempt to quit after planning or detection a pregnancy. Some succeed but some of do not. This situation itself can be conceptualized as a naturalistic experiment environment.

The literature was checked to determine whether an obstacle existed to selecting a pregnant group due to the possible effects of being pregnant on executive functions. Several studies have suggested that recall and memory deficits were acquired in pregnancy in some cases $(15,16)$. However, other studies found no difference in cognitive performance (including recall and memory) between pregnant and non-pregnant women $(17,18)$. In sum, there exist no consistent findings regarding the influence of pregnancy on executive functions. 
The aim of the present study was to compare the effect of impulsivity and planning ability on smoking cessation. Different aspects of impulsivity were evaluated. We compared executive functions including decision making, planning, response inhibition and impulsivity between spontaneously quitting pregnant women, continuing smoker and nonsmoker groups of pregnant women. We predicted diminished abilities for decision making and planning and increased trait impulsivity in smokers relative to control and those who can stop smoking.

\section{METHOD}

\section{Participants}

Group 1 consisted of women who continue smoking (N:27), Group 2 of pregnant women who quit smoking (N:15), Group 3 of pregnant women who never smoked (N:28) and Group 4 of non-pregnant women (N:18) The non-pregnant Group 4 was included to determine the effect of pregnancy on neuropsychological functions. The non-pregnant group consisted of smokers, quitters and women who have never smoked. All pregnant women enrolled in the study were in their second trimester, which is the most comfortable phase, because fatigue and nausea are no longer prevalent.

The diagnosis of nicotine use disorder (NUD) was confirmed according to DSM-5 criteria. Pregnant women who quit smoking were selected after 6 weeks of abstinence, during which withdrawal symptoms were already finished. The quitter participants did not take any nicotine cessation drugs.

A Structured Clinical Interview for DSMIV/Clinical Version (SCID-1) was administered to determine a comorbid psychiatric diagnosis. The result confirmed the lack of psychiatric diagnoses other than previous and current NUD for both the participants who continued to smoke and those who quit. The participants were interviewed faceto face in order to rule out the presence of organic mental disorder symptoms. Another exclusion criterion was evidence of a deficit in intellectual functioning. One pregnant woman who reported a previous academic failure was excluded after assess- ment of intelligence. Two pregnant women were also ruled out because of a history of previous depressive disorder episodes and a current diagnosis of panic disorder.

Fifteen pregnant women quit smoking at different stages of pregnancy; three $(20 \%)$ pregnant women quit while planning pregnancy, nine $(60 \%)$ pregnant women quit as soon as they learned that they were pregnant and three $(20 \%)$ pregnant women quit in later gestational weeks (the 6th, 10th and 17 th weeks, respectively).

Pregnant women who had never smoked and nonpregnant women were interviewed with SCID-1 and confirmed to have no psychiatric diagnosis. All participants had at least primary school education.

The control group was composed of age and education matched non-pregnant hospital staff (secretaries, cleaning and security staff, nurses). The control group was interviewed with SCID-I and was confirmed to have no lifetime or current psychiatric diagnosis.

The exclusion criteria for all groups included a prior diagnosis of psychiatric and mental disorders and/or women under the age of 18 .

\section{Procedure}

Informed consents were obtained from pregnant women who made routine appointments at our Gynecology and Obstetrics Outpatient Clinic. All pregnant women were asked to participate voluntarily. Pregnant women who agreed to participate were evaluated by a psychiatrist for NUD and other psychiatric diagnosis with SCID-I. All participants completed a Stroop Test, a Tower of London (TOL) Test and an Iowa Gambling Task (IGT), and other psychiatric rating evaluations. Executive function tests were conducted by a certified psychologist. Trait impulsivity was evaluated using the Barratt Impulsivity Scale. The severity of cigarette addiction was measured by the Fagerstrom test in order to assess the level of nicotine dependence. Pregnant women who stopped smoking were subjected to analyses 6 weeks after their quitting date. 
The study was carried out between September 2014 and December 2015 and was approved by the local ethics committee of Bursa Yuksek Ihtisas Education and Research Hospital.

\section{Executive function tests}

The Iowa Gambling Test measures decision making. The IGT consists of four decks; two of them are advantageous and two of them are disadvantageous. Decision-making score is calculated by the difference between advantageous and disadvantageous selections. The gain and the loss are less in advantageous decks, so advantageous decks are more profitable than disadvantageous decks in the long term. Subsequent to making random selections, normal cases initiate to avoid disadvantageous decks. The selections from disadvantageous decks are not only related to gaining a large amount of money but also losing as much and even more than gaining. The IGT consist of 100 cards, divided into five blocks with 20 cards each that represent learning phases. The five blocks correspond to four learning phases: the first 20 cards $(0-20)$ represent a guess, the second 20 cards (21-40) represent a pre-hunch, the third 20 cards (41-60) represent a hunch and the fourth (61-80) and fifth (81-100) blocks show conceptual knowledge.

The first 40 cards are conceptualised to represent decision making under ambiguity, and selections between 41 and 100 cards are classified as decision making under risk $(19,20)$. The probabilities of reward and loss are unknown when selections are performed in the first blocks. The card selections are performed via the emotions, affect and motivation in an ambiguous decision-making process. The probabilities of reward and loss are known in the last blocks. The selections are performed via previous experiences in a risky decision-making process (21).

The Stroop test measures response inhibition by naming the colour in which the word is printed while inhibiting the reading of the word. The test comprises five stages. The four stages are preparation for the fifth stage. The fifth stage involves cards written by different colour-meaned word. The time to complete while naming the colour of the word and the Stroop interference effect are measured in the fifth stage. The original paper used real cards are used for assessment.

The Tower of London is a task utilised to detect deficits in planning. Planning is an executive function that refers to the ability to complete the true steps of the task that has a certain goal. In this task, subjects should rearrange different coloured balls on peg from the initial position to the final position by using as few moves as possible.

\section{Psychometric scale}

The Barratt Impulsivity Scale (BIS-11) is a 30-item self-report questionnaire for measuring trait impulsivity. BIS-11 was designed by Patton et al. to assess impulsivity 7. Each item is rated on a 4-point Likert-type scale $(1=$ rarely/never, $4=$ almost always/always). BIS-11 consists of attentional, motor and non-planning subscales. High scores denote high levels of impulsivity. Motor impulsiveness indicates behavioural impulsivity. Attentional and non-planning impulsiveness are indicators of cognitive impulsiveness. Gulec et al. (22) modified the scale to the Turkish for reliability and validity study.

The Fagerstrom Test of Cigarette Dependence (FTDC) measures the degree of physical dependence to nicotine. The test consists of six selfreport items. High scores indicate high physical dependence (23).

\section{Statistical Analysis}

Statistical analyses were carried out using SPSS version 21.0 for Windows. Kolmogorov-Smirnov test was utilised to check for normal distribution. Chi-square test was used for categorical variables. Mann-Whitney-U test was used to assess numerical variables among pregnant and non-pregnant women. This test was applied with Bonferroni's correction to assess differences among the groups.

Binary logistic regression was carried out to investigate explained variance between quitting smoking and neuropsychological functions. 
IGT consists of 100 cards, which are divided into five groups with 20 cards each. The number of cards selected from advantageous $\mathrm{C}$ and $\mathrm{D}$ decks is subtracted from the number of selected cards from disadvantageous A and B decks. Two-way repeated-measure variance analysis was utilised to compare IGT scores of five decks among the groups and to assess ambiguous and risky decision making. Decision making under ambiguity was evaluated by the first 40 cards, and decision making under risk was measured by the 41-100 cards. GreenhouseGeisser correction was used when sphericity assumption was violated.

A $p$ value of less than 0.05 was considered to show a statistically significant result.

\section{RESULTS}

Comparison of demographic and clinical features among pregnant women who continue smoking, quit smoking, those who have never smoked, and non-pregnant women.

The comparison of demographic and clinical features among the four groups is illustrated in Table 1. The age and year of education were not signifi- cant among the groups. The planned pregnancy rate was similar among the pregnant groups. The non-planning impulsivity level was the highest among pregnant women who quit smoking. The pregnant group who quit smoking was statistically significantly more impulsive than the pregnant smoker group $(p=0.023)$, the control pregnant group $(\mathrm{p}=0.003)$ and the non-pregnant group $(\mathrm{p}=$ 0.005 ). Motor impulsivity and attentional impulsivity scores were higher in those in groups who had ever smoked than in those who had never smoked, but the difference was not statistically significant.

Pregnant women who had never smoke showed better performance on TOL than did those in the other groups. The control pregnant group showed significantly better performance than smoking pregnant women with regard to the comparison of TOL; the total number of correct moves $(\mathrm{p}=$ $0.002)$ and TOL total moves $(p=0.006)$. The groups did not show differences with respect to Stroop scores.

Comparison of demographic and clinical features between pregnant women who continued smoking and those who quit.

Table 1. Comparison of demographic and clinical features among pregnant women who continue smoking, quit smoking, those who have never smoked, and non-pregnant women.

\begin{tabular}{|c|c|c|c|c|c|c|c|c|c|c|c|}
\hline & $\begin{array}{c}\text { continue } \\
\text { smoking (1) } \\
n=27\end{array}$ & $\begin{array}{c}\text { quit } \\
\text { smoking (2) } \\
\mathrm{n}=15\end{array}$ & $\begin{array}{c}\text { ever never } \\
\text { smoke } \\
\text { pregnant } \\
\text { control (3) } \\
n=28\end{array}$ & $\begin{array}{c}\text { non- } \\
\text { pregnant } \\
\text { control (4) } \\
n=18\end{array}$ & $\mathrm{P}^{*}$ & $\begin{array}{l}\text { P** } \\
1-2\end{array}$ & $\begin{array}{l}\mathrm{P}^{* *} \\
1-3\end{array}$ & $\begin{array}{l}\mathrm{P}^{* *} \\
1-4\end{array}$ & $\begin{array}{l}\mathrm{P} * * \\
2-3\end{array}$ & $\begin{array}{l}\mathrm{P} * * \\
2-4\end{array}$ & $\begin{array}{l}\mathrm{P}^{* *} \\
3-4\end{array}$ \\
\hline Age & $27.03-5.43$ & $25-5.05$ & $26.53-4.58$ & $29.66-4.86$ & 0.088 & 0.269 & 0.572 & 0.157 & 0.283 & 0.011 & 0.069 \\
\hline $\begin{array}{c}\text { Year of } \\
\text { education }\end{array}$ & $9.33-2.54$ & $8.4-2.22$ & $9.07-3.07$ & $9.83-3.72$ & 0.544 & 0.291 & 0.751 & 0.469 & 0.504 & 0.169 & 0.406 \\
\hline $\begin{array}{c}\text { Pregnancy } \\
\text { was } \\
\text { planned } \\
\text { Yes/no }\end{array}$ & $\% 67 / \% 33$ & $\% 67 / \% 33$ & $\% 54 / \% 46$ & - & 0.544 & 1.000 & 0.322 & - & 0.407 & - & - \\
\hline $\begin{array}{l}\text { Attention } \\
\text { impulsivity }\end{array}$ & $16-2.98$ & $16.80-3.87$ & $14.92-3.53$ & $14.44-3.92$ & 0.087 & 0.579 & 0.167 & 0.063 & 0.074 & 0.044 & 0.433 \\
\hline $\begin{array}{c}\text { Motor } \\
\text { impulsivity }\end{array}$ & $19.51-3.38$ & $19.93-4.33$ & $18.14-3.90$ & $18.50-2.54$ & 0.244 & 0.843 & 0.073 & 0.339 & 0.162 & 0.412 & 0.334 \\
\hline $\begin{array}{l}\text { Non- } \\
\text { planning } \\
\text { impulsivity }\end{array}$ & $25.37-4.30$ & $28.33-3.99$ & $23.96-4.36$ & $24.50-2.99$ & 0.010 & 0.023 & 0.168 & 0.735 & 0.003 & 0.005 & 0.390 \\
\hline $\begin{array}{c}\text { TOL Total } \\
\text { correct } \\
\text { number of } \\
\text { moves }\end{array}$ & $2.18-1.71$ & $2.93-2.12$ & $3.85-2.04$ & $3-1.60$ & 0.021 & 0.269 & 0.002 & 0.176 & 0.176 & 0.692 & 0.248 \\
\hline $\begin{array}{c}\text { TOL Total } \\
\text { moves }\end{array}$ & $43.85-15.79$ & $43.13-18.29$ & $30.96-14.53$ & $45.87-34.36$ & 0.025 & 0.906 & 0.006 & 0.335 & 0.023 & 0.651 & 0.278 \\
\hline Stroop & $28.25-7.75$ & $30.27-9.01$ & $28.53-8.40$ & $23.78-5.77$ & 0.394 & 0.478 & 0.973 & 0.125 & 0.656 & 0.093 & 0.216 \\
\hline
\end{tabular}


Table 2. Comparison of demographic and clinical features between pregnant women who continued smoking and those who quit.

\begin{tabular}{ccccc}
\hline & $\begin{array}{c}\text { continue smoking } \\
\mathrm{n}=27\end{array}$ & $\begin{array}{c}\text { quit smoking } \\
\mathrm{n}=15\end{array}$ & Z/Chi square & $\mathrm{P}^{*}$ \\
\hline Age & $27.03-5.43$ & $25-5.05$ & -1.106 & 0.269 \\
\hline Year of education & $9.33-2.54$ & $8.4-2.22$ & -1.057 & 0.291 \\
\hline $\begin{array}{c}\text { Pregnancy was } \\
\text { planned } \\
\text { Yes/no }\end{array}$ & $\% 67 / \% 33$ & $\% 67 / \% 33$ & 0.000 & 1.000 \\
\hline $\begin{array}{c}\text { Smoking at previous } \\
\text { pregnancy }\end{array}$ & $\% 94 / \% 6$ & $\% 27 / \% 73$ & 14.393 & 0.001 \\
\hline $\begin{array}{c}\text { Partner smoking } \\
\text { Yes/no }\end{array}$ & $\% 81 / \% 19$ & $\% 67 / \% 33$ & 1.167 & 0.451 \\
\hline Duration of smoking & $10.55-4.11$ & $8.25-5.87$ & 0.087 \\
\hline $\begin{array}{c}\text { Fagerstrom score } \\
\text { before pregnancy }\end{array}$ & $5.18-2.25$ & $5.73-1.33$ & -1.710 & 0.495 \\
\hline Attention impulsivity & $16-2.98$ & $16.80-3.87$ & -0.682 & 0.579 \\
\hline Motor impulsivity & $19.51-3.38$ & $19.93-4.33$ & -0.555 & 0.843 \\
\hline $\begin{array}{c}\text { Non planning } \\
\text { impulsivity }\end{array}$ & $25.37-4.30$ & $28.33-3.99$ & -0.198 & 0.023 \\
\hline $\begin{array}{c}\text { TOL Total correct } \\
\text { number of moves }\end{array}$ & $2.18-1.71$ & $2.93-2.12$ & -2.279 & 0.269 \\
\hline TOL Total moves & $43.85-15.79$ & $43.13-18.29$ & -1.104 & 0.906 \\
\hline Stroop & $28.25-7.75$ & $30.27-9.01$ & -0.118 & 0.478 \\
\hline mann Whitney U test & & & -0.709 & \\
\hline
\end{tabular}

p*Mann Whitney U test

The comparison of demographic and clinical features between pregnant women who continued smoking and those quit is given in Table 2. No differences were found among the groups with respect to age or level of education. The likelihood of planning pregnancy was similar among the groups. The likelihood of a smoking partner, the time of smoking initiation and the level of physical addiction to smoking were similar among the groups. No significant difference was found with respect to Stroop and TOL performance. Smoking during a previous pregnancy was statistically higher in the pregnant group that continued smoking $(\mathrm{p}=0.001)$. The nonplanning impulsivity was significantly higher in the pregnant group that quit smoking than it was in the pregnant group that continued smoking $(\mathrm{p}=0.023)$.

Binary logistic regression analysis as a predictor of quitting smoking.

Table 3 presents the binary logistic regression analysis of predictors of quitting smoking. The logistic regression results revealed that non-planning impulsivity was a significant predictor of quitting. The percentage of the variance that was explained by non-planning impulsivity was $10 \%$. $(95 \% \mathrm{CI}$ 0.712-0.997 $\mathrm{p}=0.046$ ).

Comparison of ambiguity and risky decision-making performance across groups.

The comparison of IGT scores among the four groups is presented in Figure 1. No significant differences were found among the four groups according to ambiguity and decision-making performance $(F=1.785, p=0.156$, Figure 1$)$. No significant differences were found between pregnant women who continued smoking and those who quit in terms of ambiguity and risky decision-making performance $(\mathrm{F}=1.553, \mathrm{p}=0.220)$. Despite the lack of a statistically significant difference, the mean risky decision-making score was higher; that is, the risky decision-making performance was better in pregnant women who quit smoking than it was in the group that continued smoking.

Table 3. Binary logistic regression analysis as a predictor of quitting smoking.

\begin{tabular}{lccccc}
\hline \multicolumn{5}{c}{} \\
\hline \multicolumn{5}{c}{ Predictor of quitting smoking R square $=0.105$} \\
\hline & coefficient & & 95\%Conf. Interval & \\
\hline $\begin{array}{l}\text { Independent } \\
\text { Variables }\end{array}$ & $\mathrm{B}$ & Std. Error & P-value & Lower & Upper \\
\hline $\begin{array}{l}\text { Constant } \\
\text { Non-planning } \\
\text { impulsivity }\end{array}$ & 5.184 & 2.347 & 0.027 & & \\
\hline Dependent variable: quitting smoking & -0.172 & 0.086 & 0.046 & 0.712 & 0.997 \\
\hline
\end{tabular}


Figure 1. Comparison of ambiguity and risky decision-making performance across all four groups

\section{DISCUSSION}

This study evaluated neuropsychological differences, focusing on different aspects of trait impulsivity, impulsive choice and planning ability between pregnant women who quit smoking and those who continued. The non-planning impulsivity was significantly higher in the pregnant group that quit than in the pregnant group that continued. Non-planning impulsivity was a significant predictor of quitting. Although statistically non-significant, motor and attentional impulsivity in the group that had never smoked was lower than in the groups that had ever smoked. Pregnant women who had never smoked showed statistically significantly better performance on TOL than those in the smoker group.

One unpredicted result in this study was that nonplanning impulsivity was significantly higher in the pregnant group that quit smoking than it was in the pregnant group that continued smoking. Based on regression analysis, non-planning impulsivity was a significant predictor of quitting. Non-planning impulsivity has been conceptualised as a sum of cognitive complexity and self-control (13). Smoking cessation is associated with a readiness to change (24). Non-planning impulsivity might be an important factor in this regard. Li reported that an immediate quitting intention could be a significant predictor of successful smoking cessation (25). In addition to maintaining abstinence, initiating an attempt is important for quitting(4). In contrast to expectations, non-planning impulsivity seems to be an advantageous factor for initiating a cessation attempt, and seems to be differentiated from other dimensions of impulsivity with respect to the effect on cessation. The study reported that spontaneous quitters had attempts to quit that lasted for 6 months, a period twice as long as that of preplanned quitters. Thus spontaneous quitting is considered to be a successful method for smoking cessation (26). Although professionals recommend planning and preparing prior to smoking cessation, unplanned attempts were determined to be more successful $(27,28)$. In a previous study that evaluated ex-smokers' attitudes and experiences during smoking cessation, quitting typically included impulsivity and spontaneity (29). A high level of novelty seeking was found to be associated with improved treatment outcomes for opiate-dependent patients in the first week of abstinence (30). Similar results were found for smokers; high impulsivity levels were associated with good short-term results. In the long term however, high impulsivity levels were associated with high relapse rates (31). In contrast to the present results, Higgins reported that impulsivity was not a predictor of smoking cessation during pregnancy (32).

Although statistically not significant, all dimensions of trait impulsivity scores measured with BIS-11 were higher in the groups that had ever smoked than in those who had never smoked group. Our 
results are in line with previous reports $(33,34)$. It was reported that daily smokers were found to have higher scores of novelty seeking than those who had never smoked (10). Novelty seeking suggests an impulsivity-like trait (35). Both reward seeking and disinhibition were associated with smoking status. Reward seeking was especially associated with the persistence of smoking, and disinhibition was associated with nicotine dependence (36). A previous study revealed the combination of non-planning and motor impulsivities as rash impulsiveness, and was predictive of substance use disorders (37). The relationship between impulsivity and addiction has been conceptualised perspectivally, on the one hand, increased impulsivity is related to a tendency toward substance abuse, but on the other hand, the abused substance itself increases impulsivity (38).

No difference in attentional and motor impulsivity was found between pregnant women who quit and those who continued smoking. McCarthy reported that participants who had increased attentional impulsivity quit smoking at a low rate. However, participants who had increased motor impulsivity quit smoking at a high rate initially but had low rate for prolonged abstinence. The association between increased motor impulsivity and initial smoking cessation, considered as impulsive behaviour at the outset of a change attempt could be an advantage (7). Meanwhile, high levels of impulsivity are associated with smoking relapse (39).

Pregnant women who had never smoked showed better performance in TOL than did the other groups. The analysis was significant between the pregnant control group and the current smoker group. In line with our study, planning performance was impaired in cases of alcohol dependence (40). In contrast to our findings, Ruiter determined that smokers had intact planning ability (41). Planning ability was not different between the quitters and the current smokers. Our results are in line with a previous report stating that past and current smokers had similar planning performance when measured with TOL (42).

There are several studies evaluating decision making or as another definition impulsive choice in substance addiction, including nicotine. Decision mak- ing is impaired in substance (43) and alcohol (44) use disorders. However, not all types of addiction are related to impairments in decision making $(45,46)$. Despite the lack of statistically significant difference, the mean risky decision-making score was higher in pregnant women who quit smoking than that in the group that continue smoking. Mitchell found that the smoking group preferred immediate but smaller and easier alternative than the non-smoking group, indicating increased impulsive choice (24). Participants who could not sustain abstinence had more reward discounting rather than did the abstinent group (8). Bradstreet reported no difference between quitters and continuing smokers according to delay discounting (9). The high relapse rates of substance addiction are associated with impaired decision making (47).

Stroop test scores, which represent response inhibition, were similar among all of the groups in the present study. Impairments in attention (478) and response inhibition (49) could predict relapse. A previous study defined response inhibition as a behavioural measurement of impulsivity, and reported that current smokers had higher response inhibition impairment than did former smokers (8).

The time of smoking initiation and physical addiction to smoking were similar among all of the groups. In contrast to our results, a previous report indicated that a low level of nicotine dependence is associated with higher quitting rates (50). The likelihood of a partner smoking was similar between quitters and current smokers. Our data were not in line with the study that revealed that living with other smokers in the same home was associated with women's perinatal smoking (2). The likelihood of smoking during a previous pregnancy was statistically higher in the pregnant group who continued smoking than it was in the quitter group. Therefore, quitting smoking at pregnancy is considered a consistent phenomenon rather than a casual one. The likelihood of planning pregnancy was similar between the groups that quit and those who continued.

This study has several limitations. Firstly, the assessment of smoking behaviourwas evaluated by self-report questionnaires but not with biochemical 
tests. The participants could under report their smoking status because smoking in pregnancy is a socially unaccepted behaviour. Pregnant women who reported quitting were included in the same group of quitters regardless of whether they stopped smoking subsequent to learning of the pregnancy or prior to pregnancy. Orr demonstrated that pregnant women who stopped smoking prior to pregnancy were less likely to relapse than those who stopped subsequent to learning pregnancy (33).

Another limitation is the effect of nicotine and the withdrawal of nicotine on neurocognitive assessment. Alcohol is associated with neurocognitive deficits in working memory, and this condition is conceptualised as a long-term effect of alcohol consumption (51). In contrast to alcohol, nicotine is associated with improved performance in relation to its psychoactive effect. Nicotine withdrawal is associated with cognitive impairment, especially response inhibition, working memory and attention (46). In this study, pregnant women who stopped smoking 6 weeks from the quitting date were included. In this period, withdrawal symptoms would have already ceased.

Detailed neurocognitive tests were administered to pregnant women in order to highlight the effects of neurocognitive functions on quitting smoking. The authors think that this was the key strength of this study.

Further research is needed to confirm these results in a larger sample and in different clinical samples.

\section{CONCLUSION}

Although impulsivity seems to be a risk factor for initiating dependence and long-term relapse, nonplanning impulsivity seems to be an advantageous factor for initiating an attempt to quit smoking or a chance to change when an individual decides to quit.

Correspondence address: M. D. Buket Belkız Güngör, Prof. Dr. Mazhar Osman Bakırköy Psychiatry and Neurological Disease Training and Research Hospital, Psychiatry Clinic, Istanbul, Turkey buket.gungor@yahoo.com 


\section{REFERENCES}

1. Yazıcı AB, Yuvacı HU, Yazıcı E, Calışkan EH, Cevrioğlu AS, Erol A. Smoking, alcohol, and substance use and rates of quitting during pregnancy: is it hard to quit? Int J Womens Health 2016; 8: 549-556.

2. Orr ST, Blazer DG, Orr CA. Maternal prenatal depressive symptoms, nicotine addiction, and smoking-related knowledge, attitudes, beliefs, and behaviours. Matern Child Health J 2012; 16: 973-978.

3. Schneider S, Huy C, Schutz J, Diehl K. Smoking cessation during pregnancy: a systematic literature review. Drug Alcohol Rev 2010;29: 81-90.

4. Vangeli E, Stapleton J, Smit ES, Borland R, West R. Predictors of attempts to stop smoking and their success in adult general population samples: A systematic review. Addiction 2011; 106: 2110-2121.

5. Besson M, Forget B. Cognitive Dysfuntion, Affective States and Vulnerability to Nicotine Addiction: A Multifactorial Perspective. Front Psychiatry 2016; 21: 160.

6. Koob GF. The neurobiology of addiction: a neuroadaptational view relevant for diagnosis. Addiction 2006;101: 23-30.

7. McCarthy DE, Bold KW, Minami H, Yeh VM, Rutten E, Nadkarni SG, Chapman GB. Reliability and validity of measures of impulsive choice and impulsive action in smokers trying to quit. Exp Clin Psychopharmacol 2016; 24: 120-130.

8. Krishnan-Sarin S, Reynolds B, Duhig AM, Smith A, Liss T, McFetridge A, Cavallo DA, Carroll KM, Potenza MN. Behavioral impulsivity predicts treatment outcome in a smoking cessation program for adolescent smokers. Drug Alcohol Depend 2007; 88: 79-82.

9. Bradstreet MP, Higgins ST, Heil SH, Badger GJ, Skelly JM, Lynch ME, Trayah MC. Social discounting and cigarette smoking during pregnancy. J Behav Decis Mak 2012; 25: 502-511.

10. White TJ, Redner R, Skelly J M, Higgins S T. (2014). Examining educational attainment, prepregnancy smoking rate, and delay discounting as predictors of spontaneous quitting among pregnant smokers. Experimental and Clinical Psychopharmacology 2015, Vol. 23, No. 2, 97-108

11. Etter JF. Smoking and Cloninger's temperament and character inventory. Nicotine Tob Res 2010; 12: 919-926.

12. Kahler CW, Spillane NS, Metrik J, Leventhal AM, Monti PM. Sensation seeking as a predictor of treatment compliance and smoking cessation treat-ment outcomes in heavy social drinkers. Pharmacol Biochem Behav 2009; 93: 285-290.

13. Patton JH, Stanford MS, Barratt ES. Factor structure of the Barratt impulsiveness scale. J Clin Psychol 1995; 51: 768-774.

14. Cyders MA, Coskunpinar A. Measurement of constructs using self-report and behavioral lab tasks: Is there overlap in nomothetic span and construct representation for impulsivity? Clin Psychol Rev 2011; 31: 965-982.

15. Anderson MV, Rutherford MD. Cognitive reorganization during pregnancy and the postpartum eriod: An evolutionary perspective. Evolution Psychology 2012;10: 659-687.

16. Henry JD, Rendell PG. A review of the impact of pregnancy on memory function. J Clin Exp Neuropsychol 2007;29: 793-803.
17. Crawley RA, Dennison K, Carter C. Cognition in pregnancy and the first year post-partum. Psychol Psychother 2003;76: 6984.

18. Casey P. A longitudinal study of cognitive performance during pregnancy and new motherhood. Arch Women Ment Health 2000; 3: 65-76

19. Noel X, Bechara A, Dan B, Hanak C, Verbank P. Response inhibition deficit is involved in poor decision making under risk in nonamnesic individuals with alcoholism. Neuropsychology 2007; 21: 778-786.

20. Sinz H, Zamarian L, Benke T, Wenning GK, Delazer M. Impact of ambiguity and risk on decision making in mild Alzhemer's disease. Neuropsychologia 2008; 46: 2043-2055.

21. Sequin JR, Arseneault L, Tremblay RE. The contribution of 'cool' and 'hot' components of decision-making in adolescence: implications for developmental psychopathology. Cogn Dev 2007; 22: 530-543.

22. Gulec H, Tamam L, Gulec MY, Turhan M, Karakuş G, Zengin M, Stanford MS. Psychometric properties of the Turkish version of the Barratt impulsiveness scale-11. Bull Clin Psychopharmacol 2008; 18: 251-258. (Turkish)

23. Fagerstrom KO, Heatherton TF, Kozlowski LT. Nicotine addiction and its assestment. Ear Nose Throat J 1990; 69: 763767.

24. Prochaska JO, Velicer WF, DiClemente CC, Fava J. Measuring processes of change: applications to the cessation of smoking. J Consult Clin Psychol 1988; 56: 52052-52058.

25. Li L, Borland R, Yong HH, Fong GT, Bansal-Travers M, Qua ACK, Sirirassamee B, Omar M, Zanna MP, Fotuhi O. Predictors of smoking cessation among adult smokers in Malaysia and Thailand: Findings from the International Tobacco Control Southeast Asia Survey. Nicotine Tob Res 2010; 12: 34-44.

26. Ferguson SG, Shiffman S, Gitchell JG, Sembower MA, West R. Unplanned quit attempts -Results from a U.S. sample of smokers and ex-smokers. Nicotine Tob Res 2009; 11: 827-32.

27. West R, Sohal T. "Catastrophic" pathways to smoking cessation: Findings from national survey. BMJ 2006; 332:458-60.

28. Larabie LC. To what extent do smokers plan quit attempts? Tobacco Control 2005; 14: 425-428.

29. Smith AL, Carter SM, Dunlop SM, Freeman B, Chapman S. Measured, opportunistic, unexpected and naïve quitting: a qualitative grounded theory study of the process of quitting from the ex-smokers' perspective. BMC Public Health 2017; 17: 430.

30. Helmus TC, Downey KK, Arfken CL, Henderson MJ, Schuster CR. Novelty seeking as a predictor of treatment retention for heroin dependent cocaine users. Drug Alcohol Depend 2001; 61: 287-295.

31. Agboola SA, McNeill AD, Coleman TJ, Leonardi-Bee JA. A systematic review of the effectiveness of smoking relapse prevention interventions for abstinent smokers. Addiction 2010; 105: 1362-1380.

32. Higgins ST, Heil SH, Badger GJ, Skelly JM, Solomon LJ, Bernstein IM. Educational disadvantage and cigarette smoking during pregnancy. Drug Alcohol Depend 2009; 104: 100-105. 
33. Mitchell SH. Measures of impulsivity in cigarette smokers and non-smokers. Psychopharmacology 1999; 146: 455-464.

34. Bernow N, Kruck B, Pfeifer P, Lieb K, Tüscher O, Fehr C. Impulsiveness and venturesomeness in German smokers. Nicotine Tob Res 2011; 13: 714-721.

35. Smith GT, Fischer S, Cyders MA, Annus AM, Spillane NS, McCarthy DM. On the validity and utility of discriminating among impulsivity-like traits. Assessment 2007; 14: 155-170.

36. Flory JD, Manuck SB. Impulsiveness and cigarette smoking. Psychosom Med 2009; 71: 431-437.

37. Gullo MJ, Ward E, Dawe S, Powell J, Jackson CJ. Support for a two-factor model of impulsivity and hazardous substance use in British and Australian young adults. J Res Pers 2011; 45: $10-18$.

38. Perry JL, Carroll ME. The role of impulsive behavior in drug abuse. Psychopharmacology 2008; 200: 1-26.

39. Doran N, Spring B, McChargue D, Pergadia M, Richmond M. Impulsivity and smoking relapse. Nicotine Tob Res 2004; 6: 641-647.

40. Noel X, Van der Linden M, Schmidt N, Sferrazza R, Hanak C, Le Bon O, De Mol J, Kornreich C, Pelc I, Verbanck P. Supervisiory attentional system in nonamnesic alcoholic men. Arch Gen Psychiatry 2001; 58: 1152-1158.

41. Ruiter MB, Veltman DJ, Goudrian AE, Oosterlaan AE, Sjoerds Z, Brink W. Response perseveration and ventral prefrontal sensitivity to reward and punishment in male problem gamblers and smokers. Neuropsychopharmacol 2009; 34: 1027 1038.

42. Yakir A, Rigbi A, Kanyas K, Pollak Y, Kahana G, Karni O, Eitan R, Kertzman S, Lerer B. Why do young women smoke? III. Attention and impulsivity as neurocognitive predisposing factors. European Neuropsychopharmacol 2007; 17: 339-351.

43. Toor D, Roozen HG, Evans BE, Rombout L, Wetering BJM, Vingerhoets AJJM. The effects of psychiatric distress, inhibition, and impulsivity on decision making inpatients with substance use disorders: A matched control study. J Clin Exp Neuropsychol 2011; 33: 161-168.

44. Tomassini A, Struglia F, Spaziani D, Pacifico R, Stratta P, Rossi A. Decision Making, impulsivity, and personality traits in alcohol-dependent subjects. Am J Addict 2012; 21: 263-267.

45. Bechara A, Damasio H. Decision making and addiction: Impaired activation of somatic states in substance dependent individuals when pondering decisions with negative future consequences. Neuropsychologia 2002: 40; 1675-1689.

46. Bechara A, Martin EM. Impaired decision making related to working memory deficits in individuals with substance addictions. Neuropsychology 2004: 18; 152-162.

47. De Wilde B, Verdejo-García A, Sabbe B, Hulstijn W, Dom G. Affective decision-making is

predictive of three-month relapse in polysubstance-dependent alcoholics. Eur Addict Res. 2013; 19: 21-28

48. Humfleet GL, Prochaska JJ, Mengis M, Cullen J, Munoz R, Reus V, Hall SM. Preliminary evidence of the association between the history of childhood attention-deficit/hyperactivity disorder and smoking treatment failure. Nicotine Tob Res 2005; 7: 453-460.

49. Ashare RL, Falcone M, Lerman C. Cognitive function during nicotine withdrawal: Implications for nicotine dependence treatment. Neuropharmacology 2014; 76: 1-25.

50. Pisinger C, Vestbo J, Borch-Johnsen K, Jorgensen T. Smoking cessation intervention in a large randomised population-based study. The Inter99 study. Prev Med 2005; 40: 285292.

51. Lawrence AJ, Luty J, Bogdan NA, Sahakian BJ, Clark L. Problem gamblers share deficits in impulsive decision-making with alcohol-dependent individuals. Addiction 2009; 104: 10061015. 